\title{
PENGARUH PEMBERIAN SELEDRI (APIUM GRAVEOLENS L.) TERHADAP PENURUNAN HIPERKOLESTEROLEMIA PADA LANSIA DI PANTI WREDA DARMA BHAKTI KASIH SURAKARTA
}

\author{
Hartono, Siti Handayani \\ Kementerian Kesehatan Politeknik Kesehatan Surakarta Jurusan Keperawatan
}

\begin{abstract}
Celery, Hypercholesterolemia. Dyslipidemia is a lipid metabolic disorder characterized by elevated total cholesterol, LDL cholesterol, triglycerides above normal values and a decrease in HDL cholesterol. In traditional medicine, herb celery has been used as a medicine to lower cholesterol levels because of the content of unsaturated fatty acids in celery plants. The purpose of this study was to determine the effect of celery extract on the decrease of hypercholesterolemia in Elderly. Type The design of this study is quasi experimental with one group pre test post test design. The population in this study were all elderly in Panti Wreda Darma Bhakti Kasih Surakarta in 2016 with total sampling that is all respondents of the research after examination total cholesterol, triglycerides and LDL at Parahita Diagnostic Center Surakarta Laboratory with high cholesterol result of 29 people. Result of Analyst Paired t-test Total Cholesteol levels before and after giving Celery extract in Elderly showed P value 0.029 which means there is influence between before and after giving Celery extract. Result of Willcoxon test analysis of Triglyceride level before and after giving Celery extract in Elderly obtained $P$ value: 0,414 which means no influence between before and after giving Celery extract. The results of Willcoxon test analysis of LDL levels before and after giving Celery extract in Elderly obtained $P$ value: 0,102 which means no influence between before and after giving extract Celery
\end{abstract}

Keywords: Celery, Hypercholesterolemia

Abstrak: Seledri, Hiperkolesterolemia. Dislipidemia adalah kelainan metabolisme lipid yang ditandai peningkatan kolesterol total, kolesterol LDL, trigliserida di atas nilai normal serta penurunan kolesterol HDL. Pada pengobatan tradisional, sari air herba seledri telah digunakan sebagai obat untuk menurunkan kadar kolesterol oleh karena adanya kandungan asam lemak tidak jenuh didalam tanaman seledri. Tujuan penelitian ini adalah untuk Untuk mengetahui pengaruh pemberian ekstrak seledri terhadap penurunan hiperkolesterolemia pada Lansia. Jenis Rancangan penelitian ini adalah quasi experimental dengan one group pre test post test design. Populasi dalam penelitian ini adalah seluruh Lansia yang di Panti Wreda Darma Bhakti Kasih Surakarta tahun 2016 dengan total sampling yaitu seluruh responden penelitian yang setelah dilakukan pemeriksaan kadar kolerterol total, trigliserida dan LDL di Laboratorium Parahita Diagnostic Center Surakarta dengan hasil kolesterol tinggi sejumlah 29 orang. Hasil Analis Paired t-test kadar Kolesteol Total sebelum dan setelah pemberian ekstrak Seledri pada Lansia menunjukkan $\mathrm{P}$ value 0,029 yang artinya ada pengaruh antara sebelum dan sesudah pemberian ekstrak Seledri. Hasil analisis uji Willcoxon kadar Trigliserida sebelum dan setelah pemberian ekstrak Seledri pada Lansia diperoleh nilai 
P : 0,414 yang artinya tidak ada pengaruh antara sebelum dan sesudah pemberian ekstrak Seledri. Hasil analisis uji Willcoxon kadar LDL sebelum dan setelah pemberian ekstrak Seledri pada Lansia diperoleh nilai P : 0,102 yang artinya tidak ada pengaruh antara sebelum dan sesudah pemberian ekstrak Seledri

Kata Kunci : Seledri, Hiperkolesterolemia

\section{PENDAHULUAN}

Kolesterol merupakan komponen lemak yang berupa sterol banyak di dalam tubuh, bentuknya dapat sebagai kolesterol bebas ataupun terikat pada asam lemak sebagai kolesterilester. Umumnya kolesterol dalam sel-sel darah otot, hepar, dan jaringan lain dalam bentuk bebas sedangkan dalam darah dan limfe terlihat sebagai kolesterilester.

Kolesterol secara alami dibentuk oleh tubuh selebihnya diperoleh melalui makanan, seperti kuning telur, otak, daging dan hati. Kolesterol merupakan unsur penting dalam tubuh yang diperlukan untuk pembentukan dinding sel dan sebagai bahan baku beberapa hormon yang mengatur proses kimiawi di dalam tubuh.

Menurut Perkeni 2012, bahwa kolesterol dalam jumlah tinggi di dalam darah akan bisa menyebabkan arteriosklerosis yang selanjutnya akan menyebabkan kelainan kardiovaskuler. Jika aterosklerosis ini terjadi di pembuluh darah jantung, maka bisa penyakit jantung koroner dan apabila penggumpalan darah yang bercampur dengan lemak yang menempel di pembuluh darah akan menyebabkan serangan jantung terutama kadar kolesterol total darah mencerminkan kandungan kolesterol pada LDL (Low Density Lipoprotein). Kolesterol LDL merupakan jenis kolesterol jahat karena bisa menimbun pada dinding dalam dari pembuluh darah terutama pembuluh darah kecil yang menyuplai makanan ke jantung dan otak. Timbunan lemak semakin lama semakin tebal dan keras yang dinamakan arteriosklerosis dan akhirnya menyumbat aliran darah tersebut.

Hiperkolesterolemia adalah salah satu gangguan kadar lemak dalam darah (dislipidemia) yang mana kadar kolesterol dalam darah lebih dari $240 \mathrm{mg} / \mathrm{dl}$. (Perkeni, 2012). Hiperkolesterolemia berhubungan erat dengan kadar kolesterol LDL di dalam darah. Dislipidemia adalah kelainan metabolisme lipid yang ditandai peningkatan kolesterol total, kolesterol LDL, trigliserida di atas nilai normal serta penurunan kolesterol HDL.

Seledri (Apium graveolens L.) ini umunya di gunakan oleh banyak orang sebagai salah satu bumbu masakan. Seledri sudah di kenal sangat lama di Indonesia dan tidak di ketahui secara pasti dari mana asal muasal tumbuhan ini.

Sejarah tumbuhan seledri masuk ke Indonesia melalui orang-orang Belanda pada zaman penjajahan dahulu, yang mana pada zaman itu tumbuhan ini dimanfaatkan sebagai penyedap Sup, oleh karena itulah banyak orang di Indonesia menyebut daun seledri ini sebagai daun sup atau daun sop. Selain itu daun seledri juga digunakan sebagai tanaman obat. Pada pengobatan tradisional, sari air herba seledri telah digunakan sebagai obat untuk menurunkan kadar kolesterol oleh karena adanya kandungan asam lemak tidak jenuh didalam tanaman seledri. Penggunaan obat-obatan tradisional yang 
dapat digunakan untuk menurunkan kolesterol diantaranya adalah 'Daun Seledri' dalam bentuk Jus seledri. Seledri kaya magnesium dan zat besi. yang memberi gizi pada sel darah, membersihkan dan membuang deposit lemak, dan membuang sisa metabolisme yang menumpuk.

Penelitian Harmilah dkk, (2014) bahwa diketahui bahwa Jus seledri menurunkan tekanan darah pada pasien dengan hipertensi essensial setelah pemberian selama 7 hari dengan dosis $3,88 \mathrm{gr} / \mathrm{kg} \mathrm{BB}$.

Penelitian Juheni 2002 menjelaskan bahwa pemberian sari air herba seledri secara oral, dengan dosis yang bervariasi untuk mengetahui dan memperoleh dosis yang efektif dalam menurunkan kadar kolesterol dan lemak pada tikus putih. Demikian juga hasil penelitian Febrina E dkk, (2009) bahwa aktivitas ekstrak etanol seledri (Apium graveolens L.) terhadap kolesterol total, trigliserida, $L D L$-kolesterol,dan $H D L$ kolesterol pada tikus menunjukkan bahwa ekstrak etanol herba seledri (Apiumgraveolens L.) pada dosis 25 $\mathrm{mg} / 200 \mathrm{~g}$ bobot badan dan $50 \mathrm{mg} / 200 \mathrm{~g}$ bobot badan tikus dapat menurunkan kadar kolesterol total, trigliserida, dan $L D L$-kolesterol plasma secara signifikan sedangkan terhadap kadar $H D L$-kolesterol plasma mengalami kenaikan secara signifikan.

Berdasarkan latar belakang diatas peneliti tertarik untuk melakukan penelitian tentang pengaruh pemberian Seledri terhadap penurunan hiperkolesterolemia pada Lansia di Panti Wreda Darma Bhakti Kasih Surakarta. Adapun rumusan masalah penelitian ini adalah apakah pemberian
Seledri dapat berpengaruh pada penurunan kadar Hiperkolesterolemia pada Lansia?

\section{METODE PENELITIAN}

Rancangan penelitian ini adalah quasi experimental dengan one group pre test post test design sebagai berikut :

\section{Pre test Intervensi post test $\mathrm{O} \longrightarrow \mathrm{X} \longrightarrow \mathrm{O} 2$ \\ Dalam penelitian ini dilakukan} pemeriksaan kadar kolesterol total, Trigliserida dan LDL sebelum melakukan tindakan intervensi atau pretest (O1) kemudian responden diberi perlakuan dengan pemberian ekstrak Seledri selama 7 hari dengan dosis 1,7 gr/ hari terbagi mejadi 2 dosis yaitu $850 \mathrm{mg}$ pagi setelah makan dan $850 \mathrm{mg}$ sore setelah makan, kemudian diukur kembali kadar kolesterolnya. Selanjutnya peneliti membandingkan perubahan-perubahan yang terjadi setelah adanya eksperiment.

Populasi adalah seluruh Lansia yang di Panti Wreda Darma Bhakti Kasih Surakarta tahun 2016 yang berjumlah 51 orang. Kemudian populasi tersebut di lakukan tes skrining primer menggunakan test sederhana, Lansia yang diperoleh dengan hasil kolesterol tinggi dilanjutkan dengan pengambilan sampel darahnya untuk diperiksa kadar kolesterol total, trigliserida dan LDL di Laboratorium Parahita Diagnostic Center Surakarta. Dari hasil pemeriksaan Laboratorium diperoleh 29 responden dengan angka kolesterol tinggi. Dari sejumlah 29 orang tersebut memenuhi kriteria inklusi dan ekslusi dengan teknik total sampling selanjutnya di jadikan sampel penelitian.

Instrumen Penelitian yang digunakan adalah :

1) lembar biodata responden untuk mengetahui nama responden dengan 
menggunakan kode, umur responden, jenis kelamin responden,

2) Ekstrak seledri dengan cara pembuatan melalui tahap-tahap yaitu : pembuatan serbuk daun seledri, pembuatan ekstrak maserasi daun seledri hingga diperoleh ekstrak etanol seledri yang dipekatkan dalam rotary evaporator dengan suhu 50$60^{\circ}$ C. Ekstrak kental disimpan dalam lemari pendingin. Selanjutnya ekstrak kental dimasukkan ke dalam mortar dengan ditambahkan aerosil (bahan pengering ekstrak) digerus hingga terbentuk ekstrak kering. Ekstrak kering selanjutnya dimasukkan ke dalam cangkang kapsul,

3) Lembar observasi digunakan untuk mencatat data kadar kolesterol total, trigliserida dan LDL pre dan post test

Analisa ntuk mengetahui pengaruh pre dan post test variabel penelitian dilakukan uji normalitas. Hasil uji normalitas kadar Kolerol total pre test adalah $\mathrm{p}=0,20$ dan post test nlai $\mathrm{p}=0,1$ yang artinya bahwa data tersebut berdistribusi normal sehingga mengguakan uji Paired t-test. Hasil uji normalitas kadar Trigliserida pre test adalah $\mathrm{p}=0,02$ dan post test nilai $\mathrm{p}=$ 0,09 berarti data tersebut berdistribusi tidak normal maka menggunakan uji Wilcoxon. Hasil uji normalitas kadar LDL pre test adalah $\mathrm{p}=0,02$ dan post test nlai $\mathrm{p}=0,22$ yang berarti data tersebut pre test normal dan post test berdistribusi tidak normal sehingga menggunanakan uji alternatif (Wilcoxon).

\section{HASIL PENELITIAN}

Penelitian ini dilakukan di Panti Wreda Darma Bhakti Kasih Surakarta dengan jumlah populasi 51 orang. Sampel yang sesuai kriteria inklusi dan ekslusi sebanyak 29 responden. Kemudian terhadap 29 responden tersebut diberi perlakuan dengan pemberian ekstrak Seledri selama 7 hari dengan dosis $1,7 \mathrm{gr} /$ hari terbagi mejadi 2 dosis yaitu $850 \mathrm{mg}$ pagi setelah makan dan $850 \mathrm{mg}$ sore setelah makan. Setelah hari ke VII dari 29 responden drop out 9 sehingga responden hanya tinggal sejumlah 20 responden. Terhadap 20 responden tersebut pada hari ke 8 dilakukakan pemeriksaan Laboratorium kembali di Parahita Diagnostic Center Surakarta untuk mengetahui perubahan kadar Kolerterol total, Trigliserida dan LDL dapat digambarkan dalam bentuk table distribusi frekwensi sebagai berikut

\section{Deskripsi data jenis kelamin}

Dari 20 responden diketahui bahwa responden terbanyak adalah jenis kelamin perempuan 16 responden yaitu $80 \%$.

\section{Deskripsi data umur}

Dari 20 responden diketahui bahwa $100 \%$ responden umurnya di atas 60 tahun.

\section{Deskripsi data kadar Kolesterol total darah sebelum dan setelah pemberian ekstrak Seledri}

Diketahui bahwa kadar Kolesterol total sebelum pemberian ekstrak Seledri terbanyak adalah batas tinggi yaitu 50\% sebanyak 10 responden, yang optimal $35 \%$ sebanyak 7 responden dan kategori tinggi $15 \%$ sebanyak 3 orang.

Sedangkan kadar Kolesterol total setelah pemberian ekstrak Seledri terbanyak adalah batas tinggi yaitu 50\% sebanyak 10 responden, yang optimal 
$30 \%$ sebanyak 6 responden, sedang dengan kategori tinggi $20 \%$ sebanyak 4 orang.

\section{Deskripsi data kadar Trigliserida sebelum dan setelah pemberian ekstrak Seledri.}

Diketahui bahwa kadar

Trigliserida sebelum pemberian ekstrak Seledri terbanyak adalah batas normal yaitu $70 \%$ sebanyak 14 responden, sedangkan yang kadar tinggi dan batas tinggi masing $15 \%$.

Sedangkan kadar Trigliserida setelah pemberian ekstrak Seledri terbanyak adalah batas normal yaitu $65 \%$ sebanyak 13 responden, yang tinggi 20\% sebanyak 4 responden, sedang dengan kategori batas tinggi $15 \%$ sebanyak 3 orang

Deskripsi data kadar LDL sebelum dan setelah pemberian ekstrak Seledri

Diketahui bahwa kadar LDL sebelum pemberian ekstrak Seledri terbanyak adalah batas mendekati optimal yaitu $70 \%$ sebanyak 14 responden.

Sedangkan kadar LDL setelah pemberian ekstrak Seledri terbanyak adalah batas mendekati optimal yaitu $60 \%$ sebanyak 12 responden

Hasil Analis Paired t-test kadar Kolesteol Total sebelum dan setelah pemberian ekstrak Seledri pada Lansia.

Kadar Kolesterol total sebelum pemberian ekstrak Seledri dengan hasil mean 211,8 dan standar deviasi 37,696 sedangkan Kadar Kolesterol total setelah pemberian ekstrak Seledri dengan hasil mean 220,35 dan standar deviasi 43,661.

Adapun hasil dari $\mathrm{P}$ value 0,029 yang artinya ada pengaruh antara sebelum dan sesudah pemberian ekstrak Seledri
Hasil analisis uji Willcoxon kadar Trigliserida sebelum dan setelah pemberian ekstrak Seledri pada Lansia

Kadar Trigliserida sebelum pemberian ekstrak Seledri dengan hasil median 105,0 dan range $49-334$ sedangkan Kadar Trigliserida sesudah pemberian ekstrak Seledri dengan hasil median 130,5 dan range $60-334$.

Adapun hasil dari $\mathrm{P}$ value 0,414 yang artinya tidak ada pengaruh antara sebelum dan sesudah pemberian ekstrak Seledri

\section{Hasil analisis uji Willcoxon kadar LDL} sebelum dan setelah pemberian ekstrak Seledri pada Lansia

Kadar LDL sebelum pemberian ekstrak Seledri dengan hasil median 142 dan range 93 - 247 sedangkan Kadar LDL sesudah pemberian ekstrak Seledri dengan hasil median 148 dan range $90-253$.

Adapun nilai $\mathrm{P}$ : 0,102 yang artinya tidak ada pengaruh antara sebelum dan sesudah pemberian ekstrak Seledri

\section{PEMBAHASAN}

Hasil Analis Paired t-test kadar Kolesteol Total sebelum dan setelah pemberian ekstrak Seledri pada Lansia menunjukkan $\mathrm{P}$ value 0,029 yang artinya ada pengaruh antara sebelum dan sesudah pemberian ekstrak Seledri, sedangkan nilai mean naik dari 211,8 menjadi 220,35 hal ini menunjukkan ada kenaikan kadar kolesterol pada lansia setelah pemberian ekstrak Seledri.

Hasil analisis uji Willcoxon kadar Trigliserida sebelum dan setelah pemberian ekstrak Seledri pada Lansia diperoleh nilai $\mathrm{P}$ : 0,414 yang artinya tidak ada pengaruh antara sebelum dan sesudah pemberian ekstrak Seledri 
demikian juga nilai median sebelum pemberian ekstrak Seledri naik dari 105 menjadi 130,5 hal ini menunjukkan ada kenaikan kadar Trigliserida sesudah pemberian ekstrak Seledri.

Hasil analisis uji Willcoxon kadar LDL sebelum dan setelah pemberian ekstrak Seledri pada Lansia diperoleh nilai $\mathrm{P}$ : 0,102 yang artinya tidak ada pengaruh antara sebelum dan sesudah pemberian ekstrak Seledri. Kemudian terlihat nilai median juga ada kenaikan dari 142 naik menjadi 148, hal ini bisa di asumsikan bahwa ada kenaikan kadar LDL pada lansia setelah pemberian ekstrak Seledri.

Dari hasil-hasil analisis di atas hal ini berbeda dengan hasil penelitian Febrina. E., Halimah. E., Sumiwi., SA (2009) yang berjudul Aktivitas Antihiperlipidemia Ekstrak Etanol Herba Seledri (Apium Graveolens L.) dari daerah Bandung Barat pada tikus putih jantan galur Wistar Hasil penelitian menunjukkan bahwa ekstrak etanol herba seledri, pada hari ke-10 menurunkan kadar kolesterol total, trigliserida, dan $L D L$ kolesterol secara bermakna. Hasil penelitian yang dilakukan oleh Juheini (2002) sari air herba seledri yang diberikan pada hewan coba yaitu tikus putih selama enam minggu perlakuan menunjukkan adanya efek menurunkan kolesterol dan lipid, namun secara statistik penurunan kadar kolesterol total dan lemak total belum bermakna. Hal juga berbeda juga dikemukakan oleh Al Sanafi, AE (2014) bahwa bahwa Apium graveolens $\mathrm{L}$ dapat menurunkan trigliserida, LDL dan VLDL dan meningkatkan HDL secara signifikan dan indikasi yang lain Apium graveolens juga mengurangi pembentukan plak arteri.

\section{KESIMPULAN DAN SARAN}

Kadar kolesterol total pada Lansia sebelum pemberian ekstrak Seledri dengan hasil mean 211,8 dan standar deviasi 37,696 sedangkan Kadar Kolesterol total setelah pemberian ekstrak Seledri dengan hasil mean 220,35 dan standar deviasi 43,661.

Kadar Trigliserida sebelum pemberian ekstrak Seledri dengan hasil median 105,0 dan range 49 - 334 sedangkan Kadar Trigliserida sesudah pemberian ekstrak Seledri dengan hasil median 130,5 dan range $60-334$.

Kadar LDL sebelum pemberian ekstrak Seledri dengan hasil median 142 dan rang 93 - 247 sedangkan Kadar LDL sesudah pemberian ekstrak Seledri dengan hasil median 148 dan range $90-253$.

Ada pengaruh antara sebelum dan sesudah pemberian ekstrak Seledri dengan nilai signifikasi 0,029 . Nilai $p<0,05$ sehingga $\mathrm{H}_{0}$ ditolak dan $\mathrm{H}_{\mathrm{a}}$ diterima, tidak ada pengaruh antara sebelum dan sesudah pemberian ekstrak Seledri terhadap penurunan Trigliserida dengan $\mathrm{P}$ value 0,414 . Nilai $p>0,05$ sehingga $\mathrm{H}_{0}$ diterima dan $\mathrm{H}_{\mathrm{a}}$ ditolak, tidak ada pengaruh antara sebelum dan sesudah pemberian ekstrak Seledri terhadap penurunan LDL dengan $P$ value 0,102 . Nilai $p>0,05$ sehingga $\mathrm{H}_{0}$ diterima dan $\mathrm{H}_{\mathrm{a}}$ ditolak.

Saran yaitu bagi penelitian dan pengembangan selanjutnya : Dapat mengunakan desain eksperimen dengan kelompok kontrol dengan jumlah responden yang sangat memadai, Pemberian perlakuan dengan dosis bertingkat dan juga menggunakan kelompok kontrol dengan pemberian obat konvensional yang sudah di patenkan, Hendaknya karakteristik umur responden termasuk usia produktif, Hendaknya 
variabel perancu di restrikasi dengan ketat.

\section{DAFTAR RUJUKAN}

Febrina. E., Halimah. E., Sumiwi., SA., 2009. Aktivitas Antihiperlipidemia Ekstrak Etanol Herba Seledri (Apium Graveolens) dari Bandung Barat. UNPAD.

Harmilah, Ekwanti, RD., Majid, A. 2014. Jus Seledri (Apium Graveolens) Menurunkan Tekanan Darah pada Pasien dengan Hipertensi. Yogyakarta.

Juheini, 2002. Manfaat Herba Seledri (Apium Graveolens L) untuk Menurunkan kolesteroldan lipid dalam Darah Tikus Putih Diet Tinggi Kolesterol dan Lemak. Makara Sain Vol 6. Di unduh tanggal 6 Agustus 2015.

Simons. L. A. 1986. Interrelation of Lipids and Lipoprotein with Coronary Artery Disease Mortality in 19 Countries, The American Journal of Cardiologi. Hal 57

Sujarweni, W. dan Endrayanto, P. 2012. Statistika untuk Penelitian. Yogyakarta : Graha Ilmu 